\title{
An investigate on relationship between moral hazard and corporate governance with earning forecast quality in the Tehran Stock Exchange
}

\author{
Fatemeh Rouhi $^{\mathbf{a}^{*}}$ and Seyed ahmad Khalifehsultani ${ }^{\mathbf{b}}$
}

${ }^{a}$ M.A. Student, Department of Accounting, School of Management, Tehran North Branch, Islamic Azad University (IAU), Tehran, Iran

${ }^{b}$ Assist.Prof. \& Faculty Member, Department of Accounting, Alzahra University, Iran

\begin{tabular}{l}
\hline A R T I C L E I N F O \\
\hline Article history: \\
Received August 25, 2012 \\
Received in revised format \\
25 September 2012 \\
Accepted 4 October 2012 \\
Available online \\
October 62012 \\
\hline Keywords: \\
Moral hazard \\
Corporate governance \\
Tehran Stock Exchange \\
Quality of earning
\end{tabular}

\section{Introduction}

Moral hazard and corporate governance are important factors in determining market transparency. During the past decade, there have been many studies associated with corporate governance. Xie et al. (2003) investigated the impact of the board of directors, the audit committee, and the executive committee as a barrier on earnings management. They demonstrated that the composition of a board

\footnotetext{
* Corresponding author. Tel: +98-912-6216325

E-mail addresses: F_Rouhi53@yahoo.com (F. Rouhi)

C 2012 Growing Science Ltd. All rights reserved. doi: $10.5267 / \mathrm{j} . \mathrm{ms} 1.2012 .10 .007$
}

\begin{abstract}
Moral hazard and corporate governance are important factors in determining market transparency. The proposed study of this paper investigates the effects of these two factors on earning quality as well as forecasted earning in Tehran Stock Exchange. We have selected some stocks based on some predefined circumstances and extracted some necessary information over the period of 2005-2010. Based on these criteria, the information of 132 firms are qualified for the proposed study of this paper using 792 years/firm from 23 industries. There are two hypotheses associated with this study. According to the first hypothesis, we investigate whether there is a relationship between board of director independency and quality of forecasted earning. In the second hypothesis, we look to find out whether there is a relationship between the size of board of directors and quality of forecasted earning. We have used three models and using ordinary regression analysis tried to test the models. Based on the results of the survey, we have concluded that moral hazard does not influence forecasted earning, significantly. However, the results of this survey concluded that there is a meaningful relationship between forecasted earning and quality of earning. In terms of members of editorial board, quality of earning has a reverse relationship with absolute deviation of forecasted earning. In other words, as the number of editorial board increases, we may expect a more precise earning estimation. The other observation is that non-board member's duties have better motivation to contribute to firms and could make some changes.
\end{abstract}


in general and of an audit committee was associated with the likelihood that a firm would engage in earnings management. Board and audit committee members with corporate or financial backgrounds were also related to firms, which had smaller discretionary current accruals (Schleicher et al., 2010). Board and audit committee meeting frequency was associated with reduced levels of discretionary current accruals. Xie et al. (2003) reported that board and audit committee activity and their members' financial sophistication are important factors in constraining the propensity of managers to involve in earnings management.

Lee (2009a) studied the effect of management earnings predictions in mitigating data asymmetry between investors and managers associated with moral hazard, and discussed how earnings guidance could facilitate monitoring. Lee showed that firms, which are more susceptible to moral hazard problems and less possible to monitor were also more likely to release annual earnings predictions, more frequently. Besides, Lee (2009) investigated how firm internal governance drives predicting decisions and showed that stronger board governance and managerial equity incentives were related to higher likelihood and frequency of prediction issuance. Lee concluded that managerial equity incentives were associated with more informative and higher quality guidance. In other words, he explained that these forecasts were more accurate, unbiased, more specific and timely, consistent with equity incentives aligning shareholders' and managers' interests regarding disclosure decisions (Lee, 2010).

Chau and Leung (2006) empirically studied the relationship between three major corporate governance attributes including family shareholding, non-executive directors and independent chairman and the existence of audit committees on a sample of 397 publicly traded firms in Hong Kong. They reported that at a medium level of family shareholding, the convergence-of-interest impact was dominant and the existence of audit committees decreased. At a high level of family shareholding, the entrenchment impact was also dominant and the existence of audit committees increased. Besides, they showed that the response of investors to audit committee existence was not associated with family shareholding when there was an independent chairman. They recommended that there was a positive relationship between the proportion of independent non-executive directors on the corporate board and audit committee existence. They also reported that the positive relationship between independent non-executive directors was relatively stronger for corporate with an independent chairman.

Dobler (2008) analyzed risk reporting incentives and their associated with regulation based on its inherent discretion, he explained that risk reporting depends on disclosure incentives.

Lee (2009b) investigated CEO performance-based remuneration in companies, which experienced improvement in financial performance but maintained various board structures. The study analyzed how such payment associated with change in financial performance and board structures by comparing the cases between Australian and Singaporean firms. The results indicated that performance pay in both countries was linked to change in performance. Nevertheless, the proportion of CEO performance-based payment in both countries did not appear to be associated with board structure. Larger firms in both countries seemed to make big implementation of performance-based remuneration. Sales revenue was likely to be implemented by firms in both countries as a yardstick for determining CEO performance pay.

Chi and Wang (2010) studied the relationship between information asymmetry and accounting conservatism by focusing on a country - Taiwan - whose institutional background was different from that of the United States. García-Meca and Sánchez-Ballesta (2011) performed an investigation on how analysts react to specific ownership structure characteristics by investigating the accuracy of their predictions after the release of the first Spanish corporate governance code and prior the IFRS adoption. They analyzed the impact of ownership concentration, bank ownership and insider 
ownership on analyst prediction errors (Mintzberg, 1983). Overall, their results demonstrated a positive and substantial impact of bank ownership on analyst prediction accuracy, which recommended that bank ownership could lead to closer monitoring of management and a reduction in analyst prediction errors. Nevertheless, the presence of big shareholders and insiders in the ownership structure of the firm did not substantially influence the accuracy of financial analysts. This research provided investors with a more refined sense of how analyst predictions could be influenced through the composition of the ownership structure in a context of high concentration of ownership, relevant presence of banks in firms as creditors, shareholders and local GAAP.

Ballas et al. (2012) investigated the accounting policy choice based on unrealized gains or losses from securities and its pricing impacts by studying the market reaction to the mark to market accounting treatment of equity investments of Greek companies over the period of 2002-2004. They gathered the necessary data for firms listed in the Athens Stock Exchange and realized that, on average, enterprises chose to take valuation profits to the income statement and losses through equity. They also reported that the valuation adjustment incorporates necessary data for market prices while the market looks at the decision to charge the valuation adjustment to equity to be a negative signal.

Schleicher et al. (2012) in a study investigated the economic consequences of the mandatory adoption of IFRS in EU countries by demonstrating which types of economies had the largest reduction in investment-cash flow sensitivity post-IFRS. They also examined whether the reduction in investmentcash flow sensitivity depends on firm size as well as economy type. They recommended that IFRS adoption could have improved the functioning of capital markets in relation to small firms in insider economies.

\section{The proposed model}

Based on the discussion we have earlier in this paper, the following two main hypotheses are investigated,

1. There is a relationship between Moral Hazard and quality of forecasted earning.

2. There is a relationship between corporate governance and quality of forecasted earning.

There are also two sub-hypotheses as follows,

1. There is a relationship between board of director independency and quality of forecasted earning.

2. There is a relationship between the size of board of directors and quality of forecasted earning.

The proposed study of this paper gathers the necessary information from Tehran Stock Exchanges over the period of 2005-2010. According to our regulation, all stocks must be tradable for the period of studies. They must have a unique fiscal year ending March and must not have changes their business model within the period of studies. The other requirement is that no financial firm including banks, insurance or holding company is permitted. Finally, the structure of board of directors must be available for study. Finally, the stocks must be accepted at least in year 2003. Based on these criteria, the information of 132 firms have been qualified for the proposed study of this paper using 792 years/firm from 23 industries.

\subsection{Variables}

\subsubsection{Quality of forecasted earning ( $F C_{-} Q U A L_{i, t+1}$ )}

In this study, we compute this figure using three variables of profit, standard deviation of profit and difference (rang) between actual and predicted earning. 


\subsubsection{Accuracy of forecasted earning (FC_ACC)}

This variable describes the accuracy of forecasted data calculated from the absolute deviation of actual price from forecasted in term of percentage.

\subsubsection{Bias of forecasted earning ( FC_BIAS )}

This factor is calculated as the difference between the actual earning from mean of forecasted earning divided by stock price at the beginning of the period.

\subsubsection{Spread (FC_SPREAD)}

This variable is calculated from the difference between the lowest and highest stock price.

\subsubsection{Estimation of corporate governance (Board_Governance)}

- In this survey, we measure corporate governance using two methods including board of director independency and size of board of director.

1. (BD_IND): Independency of board of director is calculated based on the number of Nonboard members duty

2. (BD_SIZE): The size of board of director calculated using natural logarithm of total number of editorial members.

In order to calculated corporate governance we first calculate the median of two mentioned variables and for the data where corporate governance is one when the calculated numbers exceed the median and zero, otherwise.

\subsubsection{Moral Hazard ( Moral Hazard ${ }_{i, t}$ )}

The proposed study of this paper adopts Lee's (2010) method to calculate moral hazard based on the following variables,

1. PPE: This is the net value of assets and equipments.

2. IRISK: This ratio is calculated as standard deviation of residuals obtained using linear regression of CAPM using monthly information.

3. OM: operating profit margin calculated from operating profit divided by net revenue.

4. R \& D: The is a research and development cost.

5. ADVERT: This is the direct cost of advertisement.

6. INVEST: Capital cost is calculated through operating cash flow.

7. BM: Book value on market value is calculated by dividing book value of equities by market value.

8. LEVERAGE: Leverage is calculated through dividing long term debt by total asset values.

In order calculate moral hazard, we calculate the above nine indicators and when the value exceeds the median we consider one and zero, otherwise.

\subsubsection{Controls Ci,t $_{1}$}

This control variable includes different components of concentration, fluctuation, return on equity and profitability condition as follows, 
IOCONCENT: To calculate concentration ratio we use Herfindahl-Hirschman ratio. In this method, we calculate each shareholder's ownership and then the sum of squares of the calculated ratios are considered as an indicator for this ratio.

EARNVOL: This item measures profitability fluctuations in three years period and it calculated based on calculating standard deviation of net profit divided by mean market value.

ANNRET: Annual return of shares is calculated as follows,

$R_{t}=\frac{(1+x+y) P_{t}-P_{t-1}-y P_{n}+D P S}{P_{t-1}+y P_{n}}$

where $P_{t}$ is stock price of firm i at the end of period t, $P_{t-1}$ is stock price of firm $\mathrm{i}$ at the end of period t$1, P_{n}$ is nominal stock price of firm $i, x$ is percent increase in capital from savings and $y$ is percentage of receivables and cash capital increase. In addition, DPS is dividend per share and LOSS is a dummy variable, which is equal to one when firm is profitable in a year and zero, otherwise.

2.2. Modeling formulation

The proposed model of this paper considers the following model,

FC_QUAL $L_{i, t+1}=\alpha+\sum \beta_{i}(\text { Board Governance })_{i, t}+\sum \lambda_{i}(\text { Moral Hazard })_{i, t}+\sum \varphi_{i}(\text { Controls })_{i, t}+\varepsilon_{i, t}$

FC_ACC $C_{i, t+1}=\alpha+\sum \beta_{i}(\text { Board Governance })_{i, t}+\sum \lambda_{i}(\text { Moral Hazard })_{i, t}+\sum \varphi_{i}(\text { Controls })_{i, t}+\varepsilon_{i, t}$

FC_BIAS $S_{i, t+1}=\alpha+\sum \beta_{i}(\text { Board Governance })_{i, t}+\sum \lambda_{i}(\text { Moral Hazard })_{i, t}+\sum \varphi_{i}(\text { Controls })_{i, t}+\varepsilon_{i, t}$

FC_SPREAD $D_{i, t+1}=\alpha+\sum \beta_{i}(\text { Board Governance })_{i, t}+\sum \lambda_{i}(\text { Moral Hazard })_{i, t}+\sum \varphi_{i}(\text { Controls })_{i, t}+\varepsilon_{i, t}$

\section{The results}

We have performed regression analysis using ordinary least square technique to find the estimates for Eq. (1) to Eq. (4). Table 1 shows summary of statistics for the proposed study.

\section{Table 1}

Basic statistics of the proposed model

\begin{tabular}{lcclclcc}
\hline & $\mathrm{N}$ & Mean & Std. dev. & Min & Max & Skewness & String \\
\hline FC_ACC & 783 & -0.0674 & 0.1047 & -0.8673 & 0.0000 & -3.799 & 21.614 \\
FC_BIAS & 783 & -0.0051 & 0.1244 & -0.8673 & 0.6236 & -1.356 & 16.807 \\
FC_SPREAD & 783 & 0.0664 & 0.1082 & 0.0000 & 0.8731 & 3.302 & 16.542 \\
PPE & 784 & 0.4522 & 0.8029 & 0.0000 & 9.1804 & 6.584 & 58.967 \\
PPE & 784 & 0.8483 & 5.5453 & 0.0000 & 84.281 & 11.842 & 156.60 \\
IRISK & 784 & 12.7341 & 9.9664 & 0.6030 & 84.073 & 2.810 & 14.404 \\
OM & 784 & 0.2035 & 0.1906 & -0.7524 & 0.9604 & 0.736 & 7.075 \\
R \& D & 784 & 0.0001 & 0.0008 & 0.000 & 0.0095 & 8.437 & 83.050 \\
ADVERT & 784 & 0.0019 & 0.0060 & 0.0000 & 0.0805 & 6.318 & 58.937 \\
INVEST & 784 & 0.0744 & 0.1832 & 0.0000 & 2.9984 & 9.891 & 138.29 \\
BM & 784 & 0.7175 & 0.5280 & -2.7143 & 3.5764 & 0.368 & 8.166 \\
LEVERAGE & 784 & 0.0722 & 0.0859 & 0.0000 & 0.5739 & 2.550 & 10.824 \\
IOCONCENT & 789 & 0.2835 & 0.2176 & 0.0001 & 0.8563 & 0.851 & 3.253 \\
ANNRET & 789 & 0.0778 & 0.0819 & 0.0015 & 0.6720 & 2.910 & 15.272 \\
EARNVOL & 789 & 24.666 & 66.055 & -87.030 & 477.59 & 2.677 & 14.741 \\
$R_{t}$ & 789 & 0.0709 & 0.2569 & 0.0000 & 1.0000 & 3.341 & 12.165 \\
\hline
\end{tabular}

According to the results of Table 1, we may find that there are between 783 to 789 data for each variable of the proposed model. The information of skewness and String also help us understand that that data can be estimated using ordinary least square techniques. Table 2 shows statistical observations for the regression analysis of three models. 
Table 2

Statistical results of the proposed model

\begin{tabular}{llllllll}
\hline Model & \multicolumn{2}{c}{ Jarque-Bera } & \multicolumn{2}{c}{ Breusch-P } & \multicolumn{2}{c}{ Durbin-Watson } & \multicolumn{2}{c}{ Ramsey } \\
\hline & $\mathrm{X}^{2}$ & P-Value & $\mathrm{F}$ & P-Value & D & F & P-Value \\
\hline First & 5.756 & 0.0562 & 3.626 & 0.0000 & 1.81 & 0.480 & 0.4884 \\
\hline Second & 0.503 & 0.7773 & 4.098 & 0.0000 & 2.25 & 1.608 & 0.2052 \\
\hline Third & 2.527 & 0.2825 & 8.659 & 0.0000 & 2.25 & 0.056 & 0.8118 \\
\hline
\end{tabular}

As we can observe from the results of Table 2, according to Breusch-P represents F-value are meaningful and Durbin-Watson is within the acceptable limit, which means there is no auto correlation between the residuals. Table 3 shows details of the regression analysis for three models.

Table 3

The results of regression model for three models

\begin{tabular}{|c|c|c|c|}
\hline Coefficient & Model 1 & Model 2 & Model 3 \\
\hline Intercept & $\begin{array}{l}-0.2308 \\
(-0.996)\end{array}$ & $\begin{array}{l}0.3077 \\
(1.626\end{array}$ & $\begin{array}{c}0.1528^{* *} \\
(5.026)\end{array}$ \\
\hline CGI & $\begin{array}{c}0.0479^{* *} \\
(2.111)\end{array}$ & $\begin{array}{c}0.0094 \\
(1 / 282)\end{array}$ & $\begin{array}{c}0.0119^{* *} \\
(2.671)\end{array}$ \\
\hline BD_IND & $\begin{array}{c}0.1320^{* *} \\
(2.065)\end{array}$ & $\begin{array}{c}0.0118 \\
(0.692)\end{array}$ & $\begin{array}{c}-0.0306^{* *} \\
(-2.562)\end{array}$ \\
\hline BD_SIZE & $\begin{array}{c}0.0588 \\
(0.435)\end{array}$ & $\begin{array}{l}-0.1942 \\
(-1.719)\end{array}$ & $\begin{array}{c}-0.0414^{* *} \\
(-1.376)\end{array}$ \\
\hline Moral Hazard & $\begin{array}{l}0.0001 \\
(0.019)\end{array}$ & $\begin{array}{c}-0.0061^{*} \\
(-3.441)\end{array}$ & $\begin{array}{c}-0.0021^{* *} \\
(-2.139)\end{array}$ \\
\hline PPE & $\begin{array}{c}0.0509^{* *} \\
(2.230)\end{array}$ & $\begin{array}{l}0.0144 \\
(1.282)\end{array}$ & $\begin{array}{c}-0.0256^{* *} \\
(-4.724)\end{array}$ \\
\hline $\mathrm{PPE}^{2}$ & $\begin{array}{c}-0.0080^{* *} \\
(-2.977)\end{array}$ & $\begin{array}{l}-0.0036 \\
(-1.537)\end{array}$ & $\begin{array}{c}0.0041^{* *} \\
(3.945)\end{array}$ \\
\hline IRISK & $\begin{array}{l}-0.0001 \\
(-0.186)\end{array}$ & $\begin{array}{c}0.0005^{* *} \\
(4.443)\end{array}$ & $\begin{array}{l}0.003^{* *} \\
(4.280)\end{array}$ \\
\hline OM & $\begin{array}{c}0.1155^{* *} \\
(2.079)\end{array}$ & $\begin{array}{c}-0.0792^{* *} \\
(-2.174)\end{array}$ & $\begin{array}{l}-0.0204 \\
(-0.753)\end{array}$ \\
\hline $\mathrm{R} \& \mathrm{D}$ & $\begin{array}{c}-14.899^{* *} \\
(-2.485)\end{array}$ & $\begin{array}{c}3.018 \\
(1.067)\end{array}$ & $\begin{array}{c}5.0792^{* *} \\
(2.607)\end{array}$ \\
\hline ADVERT & $\begin{array}{c}0.4388 \\
(0.3970)\end{array}$ & $\begin{array}{l}1.010^{* *} \\
(2.504)\end{array}$ & $\begin{array}{c}0 / 8194 \\
(1 / 448)\end{array}$ \\
\hline INVVEST & $\begin{array}{l}0.0130 \\
(0.437)\end{array}$ & $\begin{array}{c}0.0143 \\
(0.743)\end{array}$ & $\begin{array}{l}-0.0014 \\
(-0.171)\end{array}$ \\
\hline $\mathrm{BM}$ & $\begin{array}{c}-0.0580^{* *} \\
(-4.298)\end{array}$ & $\begin{array}{l}0.0022 \\
(0.706)\end{array}$ & $\begin{array}{c}0.0152^{* *} \\
(6.264)\end{array}$ \\
\hline LEVERAGE & $\begin{array}{l}-0.1109 \\
(-1.247)\end{array}$ & $\begin{array}{l}--0.0185 \\
(-0.391)\end{array}$ & $\begin{array}{c}0.1102^{* *} \\
(3.708)\end{array}$ \\
\hline IOCONCENT & $\begin{array}{c}-0.0028 \\
(0.038)\end{array}$ & $\begin{array}{c}0.0614^{* *} \\
(1.938)\end{array}$ & $\begin{array}{c}0.0303^{* *} \\
(5.202)\end{array}$ \\
\hline EARNVOL & $\begin{array}{c}0.1558^{* *} \\
(1.997)\end{array}$ & $\begin{array}{c}-0.146 \\
(-0.260)\end{array}$ & $\begin{array}{c}-.0229 \\
(-0.998)\end{array}$ \\
\hline ANNRET & $\begin{array}{l}0.0001 \\
(1.632)\end{array}$ & $\begin{array}{l}-0.0001 \\
(-1.841)\end{array}$ & $\begin{array}{c}-0.00011^{* *} \\
(-4.460)\end{array}$ \\
\hline LOSS & $\begin{array}{l}-0.0466 \\
(-1.787)\end{array}$ & $\begin{array}{c}0,0382^{* *} \\
(5.947)\end{array}$ & $\begin{array}{c}0 / 0647^{* *} \\
(4 / 332)\end{array}$ \\
\hline & $\begin{array}{l}F=2.409 \\
(0.0000)\end{array}$ & $\begin{array}{l}F=2.409 \\
(0.0000)\end{array}$ & $\begin{array}{l}F=3.967 \\
(0.0000)\end{array}$ \\
\hline & 0.3771 & 0.4157 & 0.5396 \\
\hline
\end{tabular}

Based on the results of regression analysis, t-student value associated with Moral_Hazard is not statistically meaningful when the level of significance is five percent. Therefore, we cannot confirm the first hypothesis of this survey. However, In the second model, t-student value associated with 
Moral_Hazard is statistically meaningful and we can confirm the first model when the level of significance is five percent. The negative sign of this variable $(-0.0061)$ means that there is a reverse relationship between Moral Hazard and deviation from profitability. In other word, when there is an increase of one unit in Moral Hazard, we may expect a reduction of 0.0061 unit in profitability. The third model also confirms the results of the second model and the coefficient of Moral Hazard is statistically meaningful when the level of significance is five percent (P-Value=0.0329). As expected, the relationship is negative and it is equal to -0.0021 and similar result of the second model for the first hypothesis holds.

From the results we have for the first model, we realize that t-student value associated with CGI is statistically meaningful ( $\mathrm{P}$-value $=0.0352$ ), when the level of significance is five percent. Therefore, the second hypothesis is confirmed. The positive value (0.0479) means that there is a positive relationship between corporate governance and precision of estimating profit. In other words, a one unit increase in corporate governance will lead to an increase of 0.0479 in precision of estimating profit. However, the second model does not confirm the results and t-student is not meaningful. Nevertheless, according to the third model, $t$-student associated with CGI is statistically meaningful. The positive coefficient means that there is a direct relationship between CGI and profit forecasting prediction deviation. In other words, when there is an increase of one unit in corporate governance, we can expect an increase of 0.0119 unit in variability in profit estimation.

\section{Conclusion}

In this paper, we have presented an empirical study to understand whether there is meaningful relationship between moral hazard and precision of forecasted earning. We have also performed an investigation to understand the relationship between corporate governance and precision of forecasted earning. The proposed study has been implemented for some listed stocks in Tehran Stock Exchange. The proposed study has used three models and using ordinary least square methods, their coefficients were estimated. Based on the results of the survey, we have concluded that moral hazard has not influence forecasted earning, significantly. However, the results of this survey concluded that there is a meaningful relationship between forecasted earning and quality of earning. In terms of members of editorial board, quality of earning has a reverse relationship with absolute deviation of forecasted earning. In other words, as the number of editorial board increases, we may expect a more precise on earning estimation. The other observation is that non-board member's duties have better motivation to contribute to firms and could make some changes.

\section{References}

Ballas, A.A., Chalevas, C., \& Tzovas, C. (2012). Market reaction to valuation adjustments for financial instruments: Evidence from Greece. Journal of International Accounting, Auditing and Taxation, 21(1), 52-61

Chau, G., \& Leung, P. (2006). The impact of board composition and family ownership on audit committee formation: Evidence from Hong Kong. Journal of International Accounting, Auditing and Taxation, 15(1), 1-15.

Chi, W., \& Wang, C. (2010). Accounting conservatism in a setting of Information Asymmetry between majority and minority shareholders. The International Journal of Accounting, 45(4), 465489.

Dobler, M. (2008). Incentives for risk reporting - A discretionary disclosure and cheap talk approach. The International Journal of Accounting, 43(2), 184-206

García-Meca, E., \& Sánchez-Ballesta, J.P. (2011). Ownership structure and forecast accuracy in Spain. Journal of International Accounting, Auditing and Taxation, 20(2), 73-82.

Lee, J. (2009a). Moral Hazard, Firms' Internal Governance and Management Earnings Forecasts (September 9, 2009). Available at http://dx.doi.org/10.2139/ssrn.1650289 
Lee, J. (2009b). Executive performance-based remuneration, performance change and board structures. The International Journal of Accounting, 44(2), 138-162

Lee, J. (2010), Moral Hazard, Firms' Internal Governance and Management Earnings Forecasts, Working Paper, Northwestern University - Department of Accounting Information \& Management, United States.

Mintzberg, H. (1983). The case for corporate social responsibility. Journal of Business Strategy, 4 (2), 3-16.

Schleicher, T., Tahoun, A., \& Walker, M. (2010). IFRS adoption in Europe and investment-cash flow sensitivity: Outsider versus insider economies. The International Journal of Accounting, 45(2), 143-168.

Solomon, J., \& Solomon, A. (2004). Corporate Governance and Accountability. John Wiley and Sons, Ltd.

Xie, B., Davidson III, W.N., \& DaDalt, P.J. (2003). Earnings management and corporate governance: the role of the board and the audit committee. Journal of Corporate Finance, 9(3), 295-316. 